\title{
Learning Character of Early Childhood Students in Elementary Schools Through Utilization of Facilities and Infrastructure
}

\author{
Ahmad Calam $^{1 凶}{ }^{\circledR}$, Suardi Yakub ${ }^{1}$, Ilham Nazaruddin², Ronald Mahmud ${ }^{3}$, Abdul Halim ${ }^{4}$ \\ Sistem Informasi, Sekolah Tinggi Manajemen Informatika dan Komputer Triguna Dharma, \\ Indonesia(1); Pendidikan Guru Sekolah Dasar, Sekolah Tinggi Keguruan dan Ilmu \\ Pendidikan Amal Bakti, Indonesia(2); Pendidikan Matematika, Sekolah Tinggi Keguruan dan \\ Ilmu Pendidikan Amal Bakti, Indonesia(3); Manajemen,Universitas Islam Kebangsaan, \\ Indonesia ${ }^{(4)}$ \\ DOI: $10.31004 /$ obsesi.v6i4.2309
}

\begin{abstract}
Abstrak
Tujuan dari penelitian ini adalah untuk mendeskripsikan standar minimal sarana kelas, pemanfaatan sarana prasarana dalam proses pembentukan karakter dalam pembelajaran, kelebihan dan faktor penghambat guru dalam menggunakan sarana prasarana dalam proses pembelajaran. Objek penelitian ini adalah siswa SD kelas awal yang berada pada fase usia dini. Penelitian ini menggunakan desain penelitian kualitatif kuantitatif (Mixed Methods). Teknik pengumpulan data menggunakan observasi, wawancara, dokumentasi dan catatan lapangan. Teknik analisis data yang digunakan adalah analisis sebelum di lapangan, analisis saat di lapangan (reduksi data, penyajian data, verifikasi), analisis setelah selesai di lapangan. Hasil penelitian menunjukkan bahwa pemenuhan standar fasilitas ruang kelas, pemanfaatan sarana prasarana dalam proses pembelajaran, Kelebihan guru adalah dapat memanfaatkan ruang kelas secara maksimal, mengikuti tata cara penggunaan sarana prasarana pendidikan secara efisien dan cermat.
\end{abstract}

Kata Kunci : pemanfaatan; prasarana, karakter; pembelajaran; sekolah dasar kelas awal

\begin{abstract}
The purpose of this study is to describe the minimum standard of classroom facilities, the use of infrastructure in the process of character building in learning, the advantages and factors that hinder teachers from using infrastructure in the learning process at SD PAB Deli Serdang. The object of this research is the early grade elementary school students who are in the early age phase. This study uses a quantitative qualitative research (Mixed Methods) design. Technique data collection using observation, interviews, documentation and field notes. The data analysis technique used is analysis before in the field, analysis while in the field (data reduction, data presentation, verification), analysis after completion in the field. The results of the study indicate that meeting the standards of classroom facilities, utilization of facilities in the learning process, the advantages of teachers are being able to make maximum use of classrooms, following procedures for using educational infrastructure carefully and carefully. Keywords : utilization, infrastructure, character, learning, elementary school first phase
\end{abstract}

Copyright (c) 2022 Ahmad Calam, et al.

$\triangle$ Corresponding author :

Email Address : calamahmad223@gmail.com (Medan, Indonesia)

Received 3 November 2021, Accepted 17 February 2022, Published 25 February 2022 


\section{INTRODUCTION}

The progress of a nation is strongly influenced by education factors. As the contents of Law Number 20 of 2005 concerning the National Education System which explains the function of national education, namely developing capabilities and shaping the character and civilization of a dignified nation, it aims to maximize the potential of human resources, students to become capable and faithful and pious people to God Almighty, have good morals, and become nationally responsible, knowledgeable, and democratic citizens. Regarding national education standards, the Government has regulated through Government Regulation of the Republic of Indonesia Number 57 of 2021 which contains 8 (eight) education standards, as described in the regulation. National Education Standards are the minimum criteria for the education system in all jurisdictions of the Republic of Indonesia. The eight national education standards are;(a) graduate competency standard (b) standardization; (c) standard process; (d) education assessment standards (e) education personnel standards (f) facilities and infrastructure standards (g) management standards (h) financing standards (National Education Standards, 2021).

The most important thing from the national education standard is the standard of facilities and infrastructure (Parada et al., 2021). This is important because it is physical and can attract people to study at school. The standard of facilities and infrastructure is a minimum criterion of standardization of education in schools which includes; study rooms, laboratory rooms, worship rooms, library rooms, playgrounds, recreation areas, workshops and other places that support the character education process, including information technology facilities that are highly developed in the community and must be owned by students.

In terms of facilities and infrastructure in more detail described in Government Regulation Number 57 Article 25 of 2021 concerning national education standards, it is stated that; 1) The standard of facilities and infrastructure is the minimum criteria for facilities and infrastructure that must be available to the Education Unit in the implementation of Education, 2) The facilities as referred to in paragraph (1) are everything that can be used as tools and equipment in achieving learning objectives, 3) The infrastructure as referred to in paragraph (1) is the basic facility needed to carry out the functions of the Education Unit, 4) The standard of facilities and infrastructure as referred to in paragraph (1) is determined by the principles, 5) The facilities and infrastructure as referred to in paragraphs (21) and (3) must be available in the Education Unit and adapted to the needs of each path, level, and type of education.(National education standards, 2021).

Meeting the standardization of good infrastructure will certainly support the learning process itself. Realizing effective learning, one of which requires adequate infrastructure.Sufficienttosupport theformer student character. As the opinion of Djamarah(2017) that facilities and infrastructure affect teaching and learning activities in schools. Students can certainly learn better and have fun if a school can meet all student learning needs. With good learning facilities and their effective and efficient use, character building can see the reality of everyday life which is a social phenomenon. This kind of understanding makes it no longer understood as a rote subject but is able to shape the character of students.

Sudjana (2014)explains that the use of learning facilities provides several benefits, including: (a) the use of learning facilities can clarify messages and information so as to facilitate and improve learning processes and outcomes; (b) increase and excite children's attention so that they can create new characters, learning motivation, more direct interaction between students and their environment and allow students to learn on their own according to their interests; (c) provide students with a general experience of events in their environment, and allow direct interaction with teachers, society, and their environment.

Some previous research on the theme of this research has been conducted Hopkins et al. (2014) explained that in research facilities and infrastructure greatly affect in the process of 
learning activities, especially mathematics learning. With the facilities and infrastructure, the learning is more weighty and can be understood by students (Firmansyah et al., 2018) . In addition to being understood by students, adequate facilities and infrastructure will have a good influence on the improvement of teacher performance and how to teach teachers, so that teachers can teach based on the inquiry.Based on previous research there are still differences in terms of objects studied, in the most important research the objects studied are facilities and infrastructure in learning mathematics in schools, while in this study the object is the facilities and infrastructure of the school in general.

Majhi \& Minati (2019) explained that the facilities and infrastructure are very important, which in the study explained that a good and complete infrastructure will affect the number of new students at the school. If the school has customary facilities of complete and adequate facilities and infrastructure, then the school will have many students who apply, and preferably if the school has inadequate facilities and infrastructure, the school will lack students. Based on previous research, there are still differences in terms of objects studied, in the most important research the objects studied are facilities and infrastructure in increasing the acceptance of new diidk participants in school, while in this study the object is the character of learning through the maximality of facilities and infrastructure.

Cheryan et al. (2014)explained that the facilities and infrastructure owned by the school, especially classroom facilities and infrastructure, greatly affect the activities of the learning process and improve student achievement. If the condition of the class is in good condition, then students will feel comfortable in learning and students can follow the learning well without any sense of excitement with the condition of the classroom. Based on previous research there are still differences in terms of objects studied, in the most important research the objects studied are special classroom facilities and infrastructure in supporting learning in schools, while in this study the object is the facilities and infrastructure of the school in general in the formation of student character.

Based on this opinion, the use of good learning facilities will make it easier for children to carry out learning activities so that children are more enthusiastic in learning and bring up independent, tenacious and enthusiastic characters in aspire to get facilities in life. On the other hand, the lack of learning facilities will cause children to become less enthusiastic and result in a decrease in the character of hard work. Therefore, the use of learning infrastructure is carried out effectively and efficiently as long as the school does not have adequate learning facilities, various efforts are made to overcome it. Character education is one of the essential aspects of the entire education system, because education is essentially humanization(Hasibuan, 2011). Moreover, in the national education system, religious and personal education occupies a very important and strategic role(Education, 2017). Character education aims to shape a person's personality through character education, and the results can be seen in real individual actions, namely good behavior, honesty, responsibility, respecting the rights of others, and hard work(Khumalo \& Mji, 2014). Elementary school as a formal educational institution tasked with preparing future young Indonesians who are skilled and have personal institutions, is prepared so that graduates have a strong character in building their own institutions.

All school facilities and infrastructure are the right tools to convey personal education expectationsto students in an interesting way and without realizing these expectations can be achieved effectively(Han, 2020). There are many research results related to facilities and infrastructure that have been studied from Cheryan et al. (2014), Hopkins et al.(2014), Majhi \& Minati (2019), both in terms of learning methods and research results by describing the relationship between infrastructure facilities and character building.This encourages researchers to examine the maximization of the use of facilities and infrastructure in character building in learning at SD PAB Deli Serdang Regency.

Taking into account the above physiological background, the researchers formulated several problems, namely how to meet the minimum limit for classroom facilities and their 
use in relation to character building, excess facilities and what factors hinder teachers from utilizing facilities and infrastructure in the PAB SD learning process? The objectives of this research are: To describe the fulfillment of the minimum limits of facilities and infrastructure in the classroom, the use of infrastructure in character building, the advantages of facilities and what factors hinder teachers from using infrastructure in the learning process at SD PAB.

\section{METHODOLOGY}

The research method used in this research is quantitative qualitative research (Mixed Methods). This method was chosen because it can explain in detail and more fully in this study.This combined method supports and requires each other, qualitative data supports and requires qualitative data, and vice versa, but the focus is not in terms of hypothesis testing but on efforts to fulfill the answers to research questions through formal data and arguments. This research was conducted at SD PAB Deli Serdang. At the time of carrying out the research, the researcher collected data through data collection techniques, namely observation, interviews, documentation and field notes. Using this technique, the pin uses the instrument as a guide in retrieving data. However, in this case it is possible for researchers to take data outside of the instruments that have been planned, because many problems may develop after researchers go directly to the field.

The first step in carrying out this research is to do a preliminary understanding with the aim of obtaining initial data that will be studied further. After that, analyze the data while in the field using the Miles and Huberman model consisting of. Then analyze the data while in the field using the Miles and Huberman model which consists of collecting. presenting and determining, drawing conclusions and verifying (drawing conclusions). Researchers conducted two analyzes of field data obtained from two observations at different times. Then formulate a description of the conclusions that will be tested for validity.

Children's development is divided into three phases, namely the first phase of childhood, maturity and adulthood. In this study, the object of research is children who are in the early grades of elementary school, because they are considered to be in the early age range. The sample of this study was the early grade elementary school students who were in an early age phase at PAB Elementary School in Deli Serdang. This research in collecting data uses 4 (four) data collection techniques, namely: Observation / Observation: (Participatory, Covert and Unstructured), Interview and Documentation. In this research activity, the data obtained from several sources were carried out before starting, in implementation and after completion in the research area were analyzed to get the essence. The results of the interviews are used as a basis for developing student work results through LKS, strengthened by library sources and studies of educational experts.

As for the analysis after entering the research area, the stages are; After taking data in the field, the next step is to make a description that contains conclusions or new findings. Findings can be in the form of a description or description of an object that was previously dim or dark so that after research it becomes clear that it can be a causal or interactive relationship, hypothesis or theory.

Data analysis for the observation sheet meets the standard of class facilities.

Determination of maximum score $=$ maximum score $\mathrm{x} 13$

$=4 \times 13=52$

Minimum score determination $=$ minimum score $x 13$

$=0 \times 13=0$

Score range $=$ max score - minimum score

$=52-0=52$

Define criteria

The criteria use a 4-level scale with the following requirements: Very Good, Good, Enough and Less

Calculating the length of the score range; 


$\begin{array}{rll}P \quad & =52: 4 \\ & =13\end{array}$

In the end, the research results will be presented in the form of percentage weights (quantitative) and measured using a descriptive analysis of percentages (qualitative). The analysis function is needed to describe the situation and the phenomena that occur. The measurement used to determine the percentage level of the answer score from the observation results is calculated by the formula:

$\%=\mathrm{n}: \mathrm{N} \times 100$

Description :

$\mathrm{n}$ : the value obtained

$\mathrm{N}$ : sum of all values

The data collected through interviews and observations were then tested for the validity of the data using Credibility Test through: Extending observations, Confirming seriousness and Triangulation (method, time and place). For more details, the validity test of this research data can be seen from Figure 1.

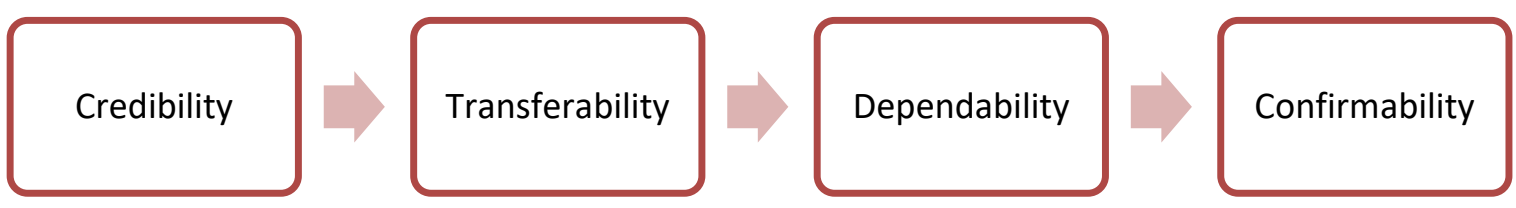

Figure 1. Data Validity Test

Source : Soendari, (2012)

\section{RESULT AND DISCUSSION}

Before examining how the use of infrastructure facilities in character building in learning, it is also necessary to examine how the standards of infrastructure are met. However, researchers focus more on classrooms because classrooms are the most important infrastructure in character building in learning and the facilities in it, although the environment and libraries are also needed, their use cannot beat the importance of classrooms. Researchers conducted research at SD PAB Deli Serdang. In this study, the tool in data collection used was in the form of an observation sheet consisting of two aspects, namely facilities and infrastructure. The infrastructure aspect consists of 1 indicator and the facility aspect consists of 12 indicators. A total of 13 indicators and each has 4 descriptors (table 1 and diagram 1).

Table 1. Achievement Results Meet Classroom Facility Standards

\begin{tabular}{lccrc}
\hline No & School Name & Total scorePercentage & Criteria \\
\hline 1. & SD PAB 5 & 46 & $87,00 \%$ & Very good \\
2. & SD PAB 19 & 46 & $87,00 \%$ & Very good \\
3. & SD PAB 20 & 42 & $81,00 \%$ & Very good \\
4. & SD PAB 21 & 42 & $81,00 \%$ & Very good \\
5. & SD PAB 22 & 41 & $79,00 \%$ & Very good \\
6. & SD PAB 23 & 44 & $85,00 \%$ & Very good \\
Total average score & 43,5 & $84,00 \%$ & Very good \\
\hline \multicolumn{5}{c}{ Source : data processed by research, 2021}
\end{tabular}




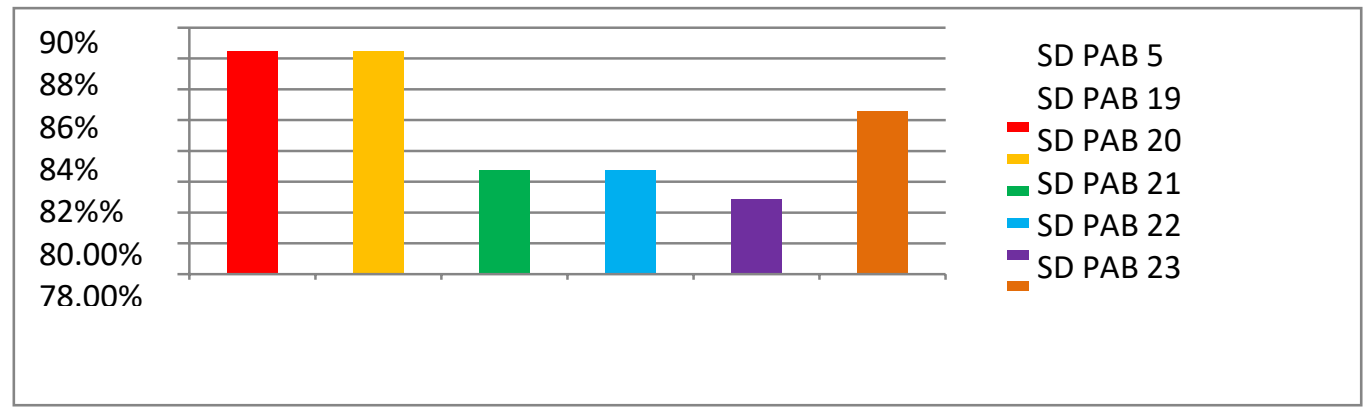

Diagram 1. Persentaseof infrastructure in the processlearning Source : data processed by research, 2021

An overview of the use of infrastructure in the processlearning is obtained from the results of observations. In this study there were 6 (six) classroom teachers as respondents. The stages of the research were carried out in 2 meetings. The tool used in data collection is a diary which consists of 2 aspects, namely effective and efficient. The aspect of effectiveness consists of 3 indicators. The effective aspect consists of 3 indications and the efficiency aspect consists of 1 indication. A total of 4 indices and each with 3 explanations. Below are the achievements obtained from each indicator in each SD PAB.

\section{An Effectiveness}

\section{Utilizing educational facilities}

The use of educational facilities during the learning process plays an important role, because it can strengthen the character and information conveyed, as well as increase and excite children's learning enthusiasm(Armalena, 2020).

The three descriptors include the use of teaching aids, the use of teaching aids, and the use of learning media. Table 2 and diagram 2 are the results of the search which show effective achievements in utilizing facilities and infrastructure in the learning process to support character building.

Table 2. OutcomesEffectiveness of Facility Utilization

\begin{tabular}{ccccc}
\hline No & School Name & Total ScorePercentage & Criteria \\
\hline 1. & SD PAB 5 & 46 & $87,00 \%$ & Very Good \\
2. & SD PAB 19 & 46 & $87,00 \%$ & Very Good \\
3. & SD PAB 20 & 42 & $81,00 \%$ & Very Good \\
4. & SD PAB 21 & 42 & $81,00 \%$ & Very Good \\
5. & SD PAB 22 & 41 & $79,00 \%$ & Very Good \\
6. & SD PAB 23 & 44 & $85,00 \%$ & Very Good \\
Total Average Score & 43,5 & $83,65 \%$ & $84,00 \%$ \\
\hline \multicolumn{5}{c}{ Source : data processed by research, 2021 }
\end{tabular}

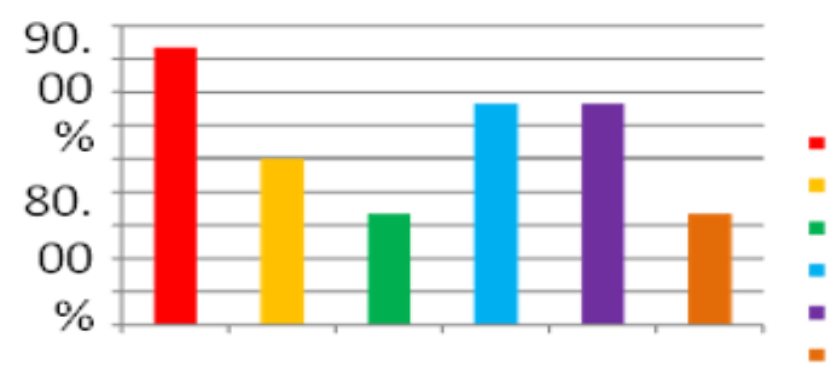

Diagram 2. Percentage of Achievement IndicatorEffective Utilization of Infrastructure Source : data processed by research, 2021 
Based on the results above, SD PAB 5 and SD PAB 19 have the highest effectiveness in the utilization of educational facilities, then there is SD PAB 23 in the next order, SD PAB 20 and 21 next, and the lowest is SD PAB 22.

Utilization of Educational Infrastructure Maximizing the use of learning facilities and infrastructure is very much needed, because facilities and infrastructure are basic things in carrying out school functions, so that maximum utilization of facilities will increasingly encourage the formation of children's character (Cinantya et al., 2018). The 3 descriptions include using the classroom, using the library and using the environment as a medium in learning, especially at elementary school age(Bhattacharya \& Mohalik, 2015).

The table 3 and diagram 3 describes the results of research on the effectiveness of the infrastructure and its achievements.

Table 3. Achievements of effective indications for the use of facilities

\begin{tabular}{|c|c|c|c|c|}
\hline No & School Name & Total Score & Percentage & Criteria \\
\hline 1. & SD PAB 5 & 46 & $87,00 \%$ & Very Good \\
\hline & SD PAB 19 & 46 & $87,00 \%$ & Very Good \\
\hline 3. & SD PAB 20 & 42 & $81,00 \%$ & Very Good \\
\hline 4. & SD PAB 21 & 42 & $81,00 \%$ & Very Good \\
\hline 5. & SD PAB 22 & 41 & $79,00 \%$ & Very Good \\
\hline 6. & SD PAB 23 & 44 & $85,00 \%$ & Very Good \\
\hline Total Average Score & 43,5 & $83,65 \%$ & $84,00 \%$ \\
\hline \multicolumn{5}{|c|}{ Source : data processed by research, 2021} \\
\hline
\end{tabular}
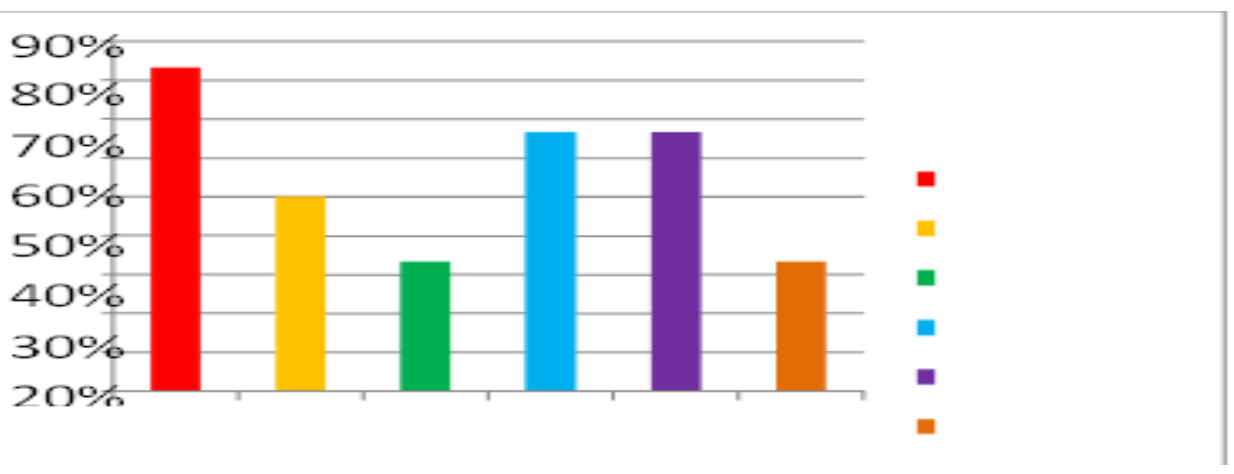

Diagram 3. Achievements Indications of Effective Utilization of Facilities

Source : data processed by research, 2021

Based on the above results, SD PAB 5 and SD PAB 19 have the highest effectiveness in the utilization of educational infrastructure, then there is SD PAB 23 in the next order, SD PAB 20 and 21 next, and the lowest is SD PAB 22.

\section{Utilization of Classroom Facilities}

Utilization of classroom facilities as a place for the learning process to take place is an interesting topic and very urgent in every school, however, the use of libraries and the environment is also needed (Herawati et al., 2020). In connection with this, the use of classroom facilities is very much needed in the formation of independent, unpretentious children's character, because the classroom is an inseparable part of the learning activity itself(Marmoah et al., 2019). There are 3 (three).

Things that must be considered with regard to classroom facilities, namely; adjust the seating position (tables and chairs), adjust the lighting (lamps and windows) and place the student's work in the space provided (shelves and long boards) 
Table 4 and Diagram 4 is the data from the research:

Table 4. Achievements Indications of Effective Utilization of Infrastructure

\begin{tabular}{|c|c|c|c|c|c|c|}
\hline \multirow{2}{*}{ No } & Name School & Meeting & Total Score & Percentage & Criteria \\
\cline { 3 - 7 } & & 1 & 2 & & & \\
\hline 1. & SD PAB 5 & 1 & 1 & 2 & $33,00 \%$ & Enough \\
\hline 2. & SD PAB 19 & 1 & 1 & 2 & $33,00 \%$ & Enough \\
\hline 3. & SD PAB 20 & 1 & 2 & 3 & $50.00 \%$ & Enough \\
\hline 4. & SD PAB 21 & 1 & 1 & 2 & $33,00 \%$ & Enough \\
\hline 5. & SD PAB 22 & 1 & 1 & 2 & $33,00 \%$ & Enough \\
\hline 6. & SD PAB 23 & 1 & 1 & 2 & $33,00 \%$ & Enough \\
\hline Average & \multicolumn{7}{|c|}{2,17} & $36,00 \%$ & Enough \\
\hline \multicolumn{7}{|c|}{ Source : data processed by research, 2021} \\
\hline
\end{tabular}

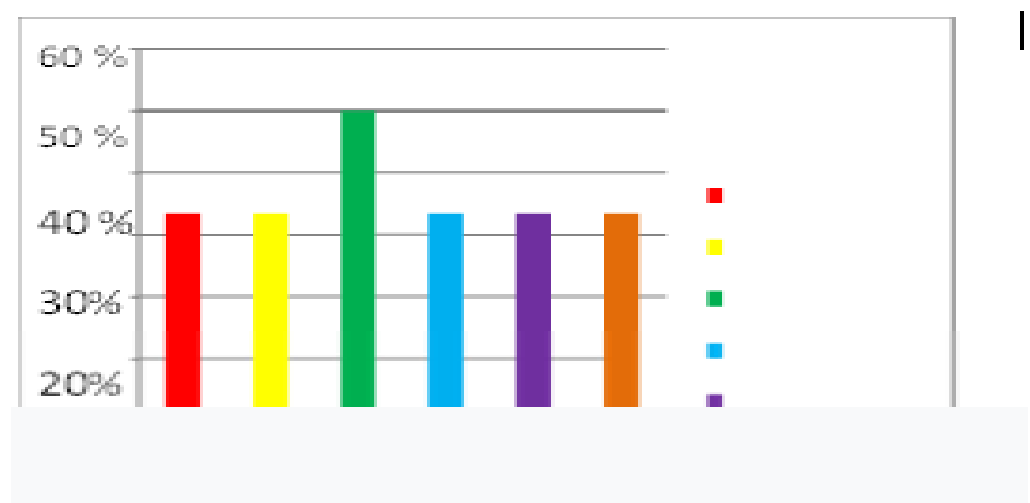

Diagram 4. AchievementsIndicationEffectiveInfrastructure Source : data processed by research, 2021

Based on the results above, SD PAB 20 has the highest effectiveness in utilizing classroom facilities, then there are SD PAB 5, SD PAB 19, SD PAB 21 and SD PAB 22 which have the same value presentation.

\section{Utilization of facilities and infrastructure}

Utilization of facilities and infrastructure in the learning process, teachers must pay attention to the principle of efficiency, meaning the use of equipment carefully and sparingly so that all existing educational equipment is not easily damaged, exhausted, lost, things like that can shape the character of a responsible child(Relisa, 2016). There are 3 (three) important things regarding the utilization of facilities and infrastructure, namely; preparation of a roster of the use of facilities and infrastructure, the time of use and following the regulations for the use of educational facilities. Table 5 and diagram 5 are the results data his research:

Table 5. Achievements Indications of Efficiency of Facilities Utilization

\begin{tabular}{|c|c|c|c|c|c|c|}
\hline No & School Name & Me & ing & Total Score & eprcen & Criteria \\
\hline & & 1 & 2 & & Tage & \\
\hline 1. & SD PAB 5 & 3 & 3 & 6 & $100 \%$ & Very Good \\
\hline 2. & SD PAB 19 & 2 & 2 & 4 & $67,00 \%$ & Good \\
\hline 3. & SD PAB 20 & 2 & 2 & 4 & $67,00 \%$ & Good \\
\hline 4. & SD PAB 21 & 2 & 2 & 4 & $67,00 \%$ & Good \\
\hline 5. & SD PAB 22 & 3 & 3 & 6 & $100 \%$ & Very Good \\
\hline 6. & SD PAB 23 & 3 & 3 & 6 & $100 \%$ & Very Good \\
\hline & Average & & & 5 & $83,00 \%$ & Very Good \\
\hline
\end{tabular}

Source : data processed by research, 2021 


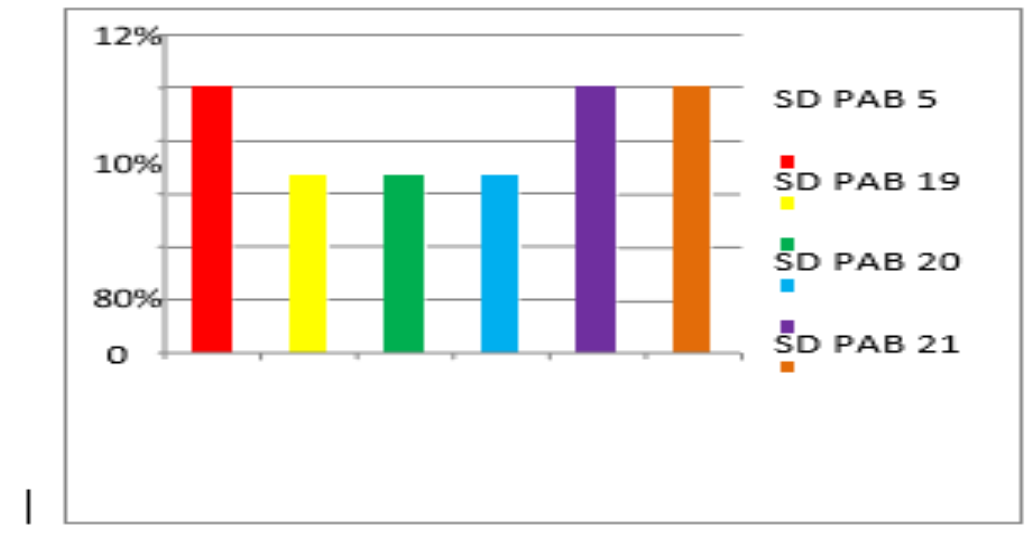

Diagram 5. AchievementsIndications of Efficiency of Facility Utilization Source : data processed by research, 2021

Based on these results, the highest efficiency of facility utilization was at SD PAB 5, 22, 23 which were both at a very good level and SD PAB 19,20,21 at a good level.

\section{Discussion}

Fulfillment of Classroom Facilities Standards at SD PAB Deli Serdang as a whole obtained very good indications. The percentage ratings from top/high to bottom/low are SD PAB 05 Klumpang Kebun and SD PAB 19 Bandar Klippa at 88.46\%, SD PAB 20 at 84.61\%, SD PAB 21 and SD PAB 22 as big as $80,77 \%$ and SD PAB 23 of $78.85 \%$ If the average result is $83.65 \%$ with a very good indication.

Efforts to meet the minimum limits of classroom facilities and infrastructure can affect the formation of character in learning activities (Kaso et al., 2018). If the effort to fulfill the facilities and infrastructure is achieved, it will further encourage the progress of the learning process, but as complete as any facilities and infrastructure owned by the school, if using them is not effective and efficient, then it is not optimal in supporting the learning process(Hamdani, 2011).

The description of 6 (six) PAB Elementary Schools in the Deli Serdang Regency area is that the facilities and infrastructure are good, especially for classroom facilities and infrastructure and the furniture in them has met the minimum standard for classrooms set out in Permendiknas No. flawless, there are still some flaws. Classrooms must accommodate a maximum of 28 students but are actually more than 28 students. There are only 2 PAB SDs that accommodate an amount that does not exceed the capacity, namely SD PAB 1902 and SD PAB 20. As for the minimum size of classrooms, all SD have met the standard with an average area of $49 \mathrm{~m} 2$. Most classrooms also have windows that allow sufficient light to read a book and provide a view to the outdoors. Classrooms also have doors that can be locked so that the safety of the furniture in the classroom can be maintained.

The student desks and chairs have met the standard of 1 student, the condition is also sturdy, stable, safe, and easy to move by students. The size is in accordance with the age group of students. The design of the suitability of the chair and the position of the back makes students comfortable in learning, and the design of the table allows students' feet to enter and step freely under the table. On average there are only 1 or 2 chairs and tables that are less stable or rocking in each school.

The teacher's desk and chair meet the standard of 1 teacher, the condition is also strong, stable and safe, easy to move and the size is adequate for work. Only SD PAB Klumpang Kebun has tables and chairs of inadequate size. 
The bookcase has met the standard onpice/room, the condition is strong, stable and safe. The cupboard is of sufficient size to store the necessary supplies for the class. However, the average cupboard cannot be locked.

Shelves to store student work in each class are not available. So that the results of student work are placed in empty parts in the classroom, for example placed on top of the cupboard, some are placed on the back floor and on an empty desk in the classroom, this is a class view that seems untidy.

The whiteboard has met the one piece/room standard, its condition is also sturdy, stable and safe. The average size of the blackboard is Length, also meets the minimum standard of $60 \mathrm{~cm} \times 120 \mathrm{~cm}$. The blackboard is placed in front of the class, so that all students can see it clearly. Most of the textbooks provided by schools have met the standard, namely 1 copy/student, the book is included in the list of books set by the Minister of Education and Culture of the Republic of Indonesia, the contents of the book support the achievement of learning objectives, the illustrations in the book are also adequate and clear. However, some PAB 05 Elementary Schools use photocopies of textbooks and some PAB 19 students use 1 package book for 2 students. This is because the existing package books are damaged and lost, so the number is limited.

Other equipment in the school such as trash cans, wall clocks, pictures of hijaiyah letters are already available in every class. However, the West-sapphire is not available in 1 unit/room, but only hand washing faucets lined up in one place in front of the school yard.

The fulfillment of teaching aids and learning media is also very good, the number of map images for each classroom is available, in good condition, meaning that it can be understood, and gives an overview that is similar to the actual shape and location. The map images in each school on average have good conditions. In addition there are also maps of various regions and globes, each school also has IT-based media (information technology) such as; projectors/OHP although in different quantities. SD PAB 19, SD PAB 20, SD PAB 21 already have 3 projectors. Then SD PAB 22 has 2 projectors, SD PAB 23 and SD PAB 05 have 1 projector.

However, the projector has not been placed permanently in the classroom, except for SD PAB 21 the projector has been permanently placed in the classroom, so its use is easier. Apart from the above, for pictures of heroes, the average school has not provided them in full. Utilization of learning facilities and infrastructure by SD PAB Deli Serdang teachers.

Utilizing the infrastructure of facilities and infrastructure in character building in the learning process with the main competence respecting the struggle of the leaders in maintaining independence by class teachers at SD PAB 05 is good. When viewed from the aspect of effectiveness, utilizing educational facilities has been running according to procedures, this is evidenced by the results of experience and observations seen from the aspect of effectiveness, utilizing educational facilities is good, this is evidenced by the results of the observation data processing an average of $55.56 \%$ with good indications and supporting data from interviews with teachers and school principals. In accordance with the opinion of Barnawi \& Arifin (2014) that in terms of effectiveness, it means that all use of learning tools in schools should be directed only to facilitate the achievement of expectations for the advancement of education in schools.

Class teachers at SD PAB 22 and SD PAB 21 have used learning tools in the form of markers, whiteboards and textbooks, but have not used teaching aids or learning media. Class teachers at SD PAB 23 and SD PAB 21 use teaching aids and learning media in the form of pictures of people praying in explaining the practice of the Prophet Muhammad's prayers that occur at prayer times 5 times per day, but the teacher does not appear using learning tools such as markers and blackboards. By using the hero image media, the teacher involves students directly in learning to shape the character, by asking students to come forward to explain the character in question and explain the struggles the character is doing. The fifth grade teachers of SD PAB 21 and SD PAB 23 have used teaching aids and technology-based 
learning media in the form of projectors to display slides and struggle films, so that students look more enthusiastic in learning. However, when teachers have used and utilized teaching aids and learning media, both visual and audiovisual, teachers mostly forget to use other learning tools, such as markers, whiteboards and even forget textbooks.

The basic problem in the use of learning aids such as markers, whiteboards is absolutely used, at least the whiteboard is used to place teaching aids in the form of community leaders or heroes, or more fully uses focus or projectors that can be connected to a laptop to display more and more complete learning media. The white board can be used to write themes and important things in learning, because the writing on the blackboard will be clearly visible and easy to understand by students even if they are sitting at the back. In the use of facilities and infrastructure in the learning process, one must also use teaching aids or learning media, because facilities and media in learning are important(Aqib, 2013).

Utilization of infrastructure in character building in learning, especially the material for the struggle to defend Indonesia's independence, obtained a score of $36.11 \%$ with sufficient criteria. On average, all classroom teachers only use the classroom when carrying out the learning process, only SD PAB 22 seemed to use the library at the second meeting. Learning outside the classroom is also good, it will bring students into the natural environment, the teacher can explain direct examples that exist in the environment Sudjana \& Rivai(2013). This strategy is more meaningful because students are exposed to the practice of prayer and the actual situation in a reasonable manner, so that it is more realistic, more factual and the truth is more accountable. The use of the environment is very suitable in learning because abstract material will become more real and meaningful. To appreciate the struggle of the characters in maintaining independence, a suitable environment is to use an artificial environment such as a museum. The technique of utilizing the artificial environment (museum) can be done by field trips. In addition to field trips, teachers should also use the library to increase student learning resources.

Based on observations of data acquisition, the average use of classroom facilities (furniture) obtained a score of $83.30 \%$ with very good criteria. The teacher straightens the sitting position of the students' desks and chairs before learning begins to look neat, and when needed for group discussion, the teacher also adjusts the sitting position to remain effective. Then, the teacher also adjusts the lighting to regulate the amount of light that enters the classroom, by turning on or off the lights and closing or opening the window curtains. The arrangement of classroom furniture is an effort made by the teacher in creating a conducive learning atmosphere.

Utilization of infrastructure in character building in learning certainly cannot be separated from various obstacles. The obstacle felt by the teacher regarding the use of infrastructure in the learning process was that there was no laboratory for practice or a place for teaching aids and there were no special officers who set it up, so that if needed the teacher had to find another class. Sometimes the use of teaching aids or learning media can clash with other classroom teachers, so they are used interchangeably.

Constraints in providing facilities and infrastructure are limited funds to finance field trips, because learning outside the classroom requires a lot of funds. One example, going to a museum requires an entrance fee and transportation costs. Thus, field trips to museums are carried out if there is an invitation from the Education Office or financed by the North Sumatra PAB organization, during the national education day event. Apart from that, there are still teachers who are not able to operate computers when using OHP or projectors.

\section{CONCLUSION}

In general, the fulfillment of standard classroom facilities is very good, and Utilization of facilities and infrastructure in the process of character building in learning obtained $a$ is good. However, there were several obstacles found, namely the lack of regular educational facilities and infrastructure, incomplete laboratories, no special officers managing educational 
infrastructure facilities, limited funds, and some teachers were not optimal in using computer technology-based media.

\section{ACKNOWLEDGMENT}

This research can be completed due to several parties who cannot be mentioned one by one. However, the writer would like to first thank Allah SWT for His blessings, then the writer would also like to thank STMIK Triguna Dharma, STKIP Amal and the Indonesian National Islamic University for their support.

\section{REFERENCES}

Aqib, Z. (2013). Contextual Learning Media Model. YramaWidya.

Armalena, A. (2020). Pengelolaan sarana dan Prasarana di Sekolah Dasar Muhammadiyah $\begin{array}{llll}\text { Kota Padang. Jurnal 89-100. } & \text { Penelitian, }\end{array}$ https://doi.org/10.32528/ipteks.v5i1.3023

Barnawi, \& Arifin, M. (2014). Management of School Facilities and Infrastructure. Ar-Ruzz Media.

Bhattacharya, D., \& Mohalik, R. (2015). Availability and Utilisation of Teaching-Learning Materials and Basic Infrastructure in Primary Schools of Contai Municipality: a Field Study. International Journal in Management and Social Science, 03(12), 152-163.

Cheryan, S., Ziegler, S. A., Plaut, V. C., \& Meltzoff, A. N. (2014). Designing Classrooms to Maximize Student Achievement. Policy Insights from the Behavioral and Brain Sciences, 1(1), 4-12. https:// doi.org/10.1177/2372732214548677

Cinantya, C., Suriansyah, A., \& Asniwati, A. (2018). The Model of Religion-Based Character Education (Multi-Site Integrated Islamic Paud Sabilal Muhtadain and Paud Islam Mawaddah Banjarmasin, Indonesia). European Journal of Education Studies. https://doi.org/10.46827/ejes.v0i0.2097

Djamarah, S. B. (2011). Study Psychology. Rineka Cipta.

Education, T. M. of N. (2017). Academic Paper on Policy Studies of Religious Science Curriculum (PAI).

Firmansyah, T., Supriyanto, A., \& Timan, A. (2018). Efektivitas Pemanfaatan Sarana Dan Prasarana Dalam Meningkatkan Mutu Layanan Di Sma Laboratorium. JMSP (Jurnal Manajemen Dan Supervisi Pendidikan), 2(3), 179-184. https://doi.org/10.17977/um025v2i32018p179

Hamdani. (2011). Teaching and Learning Strategy. Faithful Library.

Hasibuan, S. . (2011). Human Resource Management. Bumi Aksara.

Herawati, S., Arafat, Y., \& Puspita, Y. (2020). Manajemen Pemanfaatan Sarana Dan Prasarana Pembelajaran. Attractive: Innovative Education Journal, 2(3), 21-28. https://doi.org/10.51278/aj.v2i3.68

Hopkins, M., Spillane, J. P., Jakopovic, P., \& Heaton, R. M. (2014). Infrastructure redesign and instructional reform in mathematics: Formal structure and teacher leadership. Elementary School Journal, 114(2), 200-224. https://doi.org/10.1086/671935

Kaso, N., Mariani, M., Ilham, D., Firman, F., Aswar, N., \& Iksan, M. (2018). The Principal's Leadership: How to Improve the Quality of Teaching and Learning Process in State Junior High School of LuwuNo Title. Jurnal Ad'ministrare, 8(1), 49-58. https://doi.org/10.26858/ja.v8i1.19126

Khumalo, B., \& Mji, A. (2014). Exploring educators' perceptions of the impact of poor infrastructure on learning and teaching in rural South African schools. Mediterranean $\begin{array}{llll}\text { Journal of Social } & \text { Sciences, } & \text { 1521-1532. }\end{array}$ https://doi.org/10.5901/mjss.2014.v5n20p1521

Majhi, H., \& Minati, M. (2019). Infrastructural Development and Enrollment in Elementary Education in Odisha. Journal Economic Affairs, 64(2), 377-385. https://doi.org/10.30954/0424-2513.2.2019.1 
Marmoah, S., Adela, D., \& Fauziah, M. (2019). Implementation Of Facilities And Infrastructure Management In Public Elementary Schools. AL-TANZIM: Jurnal Manajemen Pendidikan Islam, 3(1), 102-134. https:/ / doi.org/10.33650/al-tanzim.v3i1.507

National Education Standards, Pub. L. No. 57 (2021).

Parada, Y. L., Sion, H., Lion, E., Harinie, L. T., \& Barbara, B. (2021). Management Of Education Infrastructure In Katingan District Elementary Schools. 7(2), 20-30.

Relisa, R. (2016). Kajian Prasarana Pendidikan Sekolah Dasar Sebagai Salah Satu Indikator Pencapaian Standar Nasional Pendidikano Title. Jurnal Pendidikan Dan Kebudayaan. https:// doi.org/10.24832/jpnk.v1i1.228

Soendari, T. (2012). Pengujian keabsahan data penelitian kualitatif. Jurusan PLB Fakulitas Ilmu PendidikanUniversitas Pendidikan Indonesia.

Standards for Educational Facilities and Infrastructure, Pub. L. No. 24 (2007).

Sudjana, N. (2014). The Basics of the Teaching and Learning Process. Sinar Baru Algesindo.

Sudjana, N., \& Rivai, A. (2013). Teaching Media. Sinar Baru Algesindo.

Taneo, S. . (2010). Study of Elementary School Learning. Director General of Basic Education, Ministry of National Education. 